\title{
“Diasporic Transnationalism": Towards a Framework for Conceptualizing and Understanding the Ambivalence of the Social Construction of "Home" and the Myth of Diasporic Nigerian Homeland Return
}

\author{
Buster C. Ogbuagu, Ph.D., M.S.W. \\ College of Arts \& Sciences \\ Department of Social Work \\ University of St. Francis \\ 500 Wilcox Street \\ Joliet, Illinois, 60435, U.S.A. \\ Email:bogbuagu@stfrancis.edu
}

\section{Doi:10.5901/jesr.2013.v3n2p189}

\section{Abstract}

In the last several decades, a large number of Nigerians have left Nigeria, their native land, to Europe and the Americas, mostly to acquire education and skills for national growth participation and self-actualization. Most who left Nigeria's shores were certain about the inevitability of their return, or were impressed by significant others on its pertinence, contingent on the dictates of the culture, values, filial piety and other social and cultural ties and encumbrances. Whereas a few completed their studies or whatever educational or skills training they sought and returned to Nigeria, this study found that most remain, even trapped. Although they continue to entertain putative thoughts about returning to be buried among their ancestors, this may never happen, leaving them ambivalent, frustrated and even discomfited about their social, structural and especially psychological construction of "Home." Although the social construction of "home" posits no issue for mainstream cultures, it is literally a matter of life and death for Diasporic Africans. The study seeks to highlight this social and psychological discomfiture of "Mental Homelessness" that is the bane of migration and transnational movements among Diasporic Africans, using Nigeria as a backdrop. It also quests for cultural competency by practitioners to seek non-linear ways to assist such Diasporic Transnationalists find a sustainable resolution to an appropriate definition and construction of "home."

Key Words: African immigrants, Diaspora, Transnationalism, deracination, deterritorialization, Nigerian immigrants, myth of homeland return, homeland development

\section{Introduction}

The Diasporic African Community comprises a large number of persons who claim Africa as their cultural homeland. In the west, this African Community is subsumed under a category called Black (Foster, 1996; Smith, 1992; James, 1981), assigned to all persons of African descent, regardless of whether they are coming from mainland Africa, the Caribbean or as descendants of former slaves in America. To this extent, the Nigerian Diaspora is a part of the Black Community, a recent occurrence in the Transnational movement discourse. This Diasporic Community comprises mainly first generation families of parents and children, aptly referred to as the 1.5 generation. Whereas a handful of Nigerians have been Diasporic residents since the 1950s and 1960s, due to their quest for the acquisition of western education and skills, most Diasporic Nigerians arrived in the west following the Nigeria/Biafra (Civil) War. Yet, other émigrés comprised a large number of refugees, contingent on the intractable beachhead of military interventions, religious persecutions, endless political unrests and ethnic/tribal conflicts, the presumption of Nigeria as a failing state, or just to enhance the quality of lives for themselves and their families (Nwankwo, 1998; Engin and Myer, 1997; Campbell, 1995; Adekson, 1981; Schwarz, 1968).

Mensah (2002) argues that the African Transnational movement increased exponentially in the 1970s across socio-economic lines, in part, owing to the globalization of enterprise. In this dispensation, Torczyner 
(1991) suggested that from 1970 up until 1991 only 1 out of 10 Blacks was born in Canada, a representation of 44.2 percent of all Blacks in Canada. However, from 1961 to 1970 less than 5 percent of all Black immigration to Canada came from Africa. With the inclusion by the Canadian government of African migrants as a somewhat "desirable" group between 1981 and 1990, Transnational migration from Africa increased, with more than 1 in 4 Black immigrants to that country being designated as born in Africa during this ten year period.

The fact of the matter is that Africans, including Nigerians, who arrived in the west-Europe and the Americas, are now residents and bona fide members and citizens of the respective countries where they landed. They work, have built physical homes and domiciles, established and maintain relationships, friendships, ties and other encumbrances in the host societies. Simultaneously, these Nigerians have consanguineal ties-mothers, fathers, siblings, extended family members, ancestral homes and cultural rituals that sustainably define them as Nigerians. Additionally, they own properties-physical homes, lands, businesses, etc. in their cultural homelands, which identifies them as members of their homelands as well. When they arrived in the west, they maintained a refrain of "I am here in the Diaspora for my children and when they establish themselves here, I shall return to Nigeria, Ghana, South Africa" or wherever their cultural homeland is. They are harangued each day to send money "home," collectively billions each year, as a part of their belongingness and contribution towards the sustenance of their family unit [as a whole], present themselves for family events, including funerals, chieftaincy events, even Christening, which some comply with. Many have vowed to be interred, when they die with their ancestors, due to the cultural norm in some parts of Africa (Ogbuagu, 2011) that mandates a deceased Diasporan to be repatriated home or be designated as a lost soul or lost one [ Efulefu].

Their children are born in the west, raised here and most have neither been to Nigeria, any part of Africa from which they are supposedly from nor have any plans whatsoever to sojourn to Nigeria. In the western host country, these Diasporic Africans, stake claim to their adopted homes, but there again, they encounter "otherness" contingent on the discourses of race, ethnicity, belief systems and other intersectionalities of exclusion. Conversely, when they return on visits to Africa or Nigeria, they stick out like a sore thumb and are perceived as outsiders, even from the place where they were born and nurtured prior to their sojourn. Those who are lucky sometimes escape with their lives, due to large scale planned assassinations, swindling by 419 ners [con artistes], including family members. Where these horrors are absent, although it is everyday lived experience in Nigeria, they face a dilapidated or non-existent infrastructure-lack of water, electricity, roads, air travel, food scarcity, sound political dispensation, safety and security, sustainable education, and a civil society all of which force them to rethink their journey back to the fatherland. This discomfiture becomes the "seed money" for the confusion and ambivalence of sustainable construction of social and psychological "home" in Nigeria or the Diaspora.

This study uses Nigeria as a microcosm of the African Diaspora, in order to construct a framework for understanding the issue of Diasporic Transnationalism, the social construction of "home" and the myth of a return to the cultural homeland that Diasporic Africans, including Nigerians face each day. It explores some of the variables that impact on their ability or unwillingness to plant social and psychological roots in the Diaspora, as well as those that create ambivalence and barriers to their constant refrain to return and settle in their cultural homeland. This condition leaves the African Diasporic persons in limbo and the middle of nowhere. It frustrates their integrational processes in the Diaspora, where they reside and daily and conscientiously contribute to nation building, or the mythical and elusive cultural homeland where they fervently and like the Israelites during their Babylonian and Assyrian deportation, pray and strive to return to. As well, this state of limbo pervasively skews their socialization and acculturation capacities on behalf of their children and generations to come. Finally, the study lays itself bare for interpretation by professionals for the purposes of interventional paradigms. In the study, intervention modalities are embedded and render themselves feasible through the acquisition of cultural competencies by counselors and practitioners, the practice of which become translatable to sustainable interventions on behalf of Diasporic persons and their families.

\section{Literature Review}

In the last two decades transnational migration has become the rule rather than the exception, owing largely to globalization and speedy transportation systems (Capps, McCabe, and Fix, 2011; Thomas, 2011). Levitt (2004) informs about the falsity of the assumption that people born and bred in an area, complete with a set of 
national, cultural and normative ways of life are likely to remain at this location for the balance of their natural lives. She further stated, that the period of borders complete with impermeable boundaries are no longer valid, because more than ever before, more and more persons are holding allegiances and ownership of two (Levitt and Schiller, 2004), sometimes, more locations. To this extent and as she argued, transnational migrants and entities are engaged in work, play, religious worship, politicking and nation building in more than one location as a tenet of transnational migration. Although transnational Diasporas spend most of their lives in the host country, they nonetheless maintain a Homeland orientation (Safran, 1991), real or imagined, as a definitive, therefore authoritative source of value, identity and loyalty. Safran (1991) distinguishes six criteria or variables pertinent to homeland orientation, four of which present as most apt and revealing in the construction of a homeland. They include the maintenance of a collective memory or myth about the homeland; perception of the ancestral homeland as the true, ideal home to which they must strive to and eventually return; a collective commitment to the maintenance or restoration and renaissance of this homeland, including its safety and prosperity; and finally, sustained personal or vicarious relationship to the homeland in ways that significantly and evidently molds one's identity and sense of solidarity.

Original conceptualization of the Diaspora was that those who leave their homelands make a sharp and definitive break with such homelands. They assumed that the trajectories of migration (Brubaker, 2005) were not bidirectional, but unidirectional in that it posited immigrationist, assimilationist, nationalist, and teleological values and stance. They also conceptualized immigration as coterminous with assimilation. On the contrary, current Diasporic paradigms disagree, vehemently, and maintain that Diasporic persons are increasingly becoming transnationalist Diasporas (Sheffer, 2003), a claim that transcends the previously held assimilationist, immigrationist paradigm.

$$
\text { Lie (1995) argues: }
$$

It is no longer assumed that immigrants make a sharp break from their homelands. Rather, premigration networks, cultures, and capital remain salient. The sojourn itself is neither unidirectional nor final...[M]ovements...follow multifarious trajectories and sustain diverse networks. Rather than the singular immigrant, scholars now detail the diversity of immigration circumstances, class backgrounds, gendered transitions, and the sheer multitude of migration experiences (p.304).

Transnational migration means that although a lot of migrants will implant their social and psychological being in the host countries, they still hold strong ties to their original homeland that are not antithetical, sometimes engaging fiercely in the social and political events that occur outside of their place of normal domicile. Levitt and Schiller (2004) argue that the Transnational migration experience involves at least three distinct categories of those who complete the migration, those left behind in the home country and receive support and remittances, and finally those who do not emigrate and also are devoid of any external support, representing also the more dispossessed. What this transnational migration of their fellow country men and women does to them is further impoverish them, since goods and services normatively remitted home evidently becomes out of reach for them.

Continues, Levitt and Schiller (2004), those who have Transnationally migrated create conditions of inequality that sees families and household of the transmigrants consume and become acclimatized to consuming goods and services that would otherwise be out of their reach. In furtherance of this inequality discourse, Levitt and Schiller state that the needs of the individual trump those of the collective, due to the discriminatory distribution of Transmigrational largesse. In this case, whereas individuals in that society, who were equally needy at some point, therefore worked or at least strove to work collectively to deal with their want, transnational migration and its appurtenances creates divisions and classes, because it selects those who receive and others who do not, further not only stunting collectivism, but also dealing a blow to communal esprit de corps.

\section{Theoretical underpinnings}

The theoretical underpinnings for this study predicate on the multitudinousness of conceptual and theoretical perspectives embedded in Diasporic and Transnational studies. In this, the emphasis for articulating Diasporic and Transnational discourses springs from the dialectical intercourse between the emergent social theories of 
nationality, ethnicity, race, culture, socialization and identity on the one hand. On the other, is the theorization of the concept of Diaspora and Transnational movements and their implications for the construction of a permanent homeland. This subjective construction of homeland presents in two facets-one is the real and the other is the putative, mythical homeland. The existence and interplay and intersectionality of the corporeal and mythical homeland then creates physical, mental and emotional tensions and turmoil in the psyche of Diasporic and Transnational entities, with no foreseeable end date for the crystallization, settlement, integration and assumption of a linear citizenship.

The African Diaspora (Alex-Assensoh, 2010) represents a growing transnational community, contingent on their historical experience with external subjugation and colonial domination over several millennia. This experience, which became exacerbated by neo-colonial manipulation and subterfuge, a part of which is embedded in the current concept of Globalization became the catalyst for forced or optionarily compulsory separation or flight from the homeland. Consequently, and over time, a sense of deterritorialization began to emerge and bred sentiments about a putative homeland, with the discourse assuming increasing dominance among the Diasporic persons. Rather than the acquiescence of a deterritorialization ethos (Eisenstadt, 2000; Tambiah, 2000), Diasporic Communities have engaged in the paradigm shift of transnationalistic interests and engagement, and the persistent mythical idea of a homeland return, with the Nigerian Diaspora as an epitome of this emergent Diasporic Transnationalism.

\subsection{Why Apply "Diaspora" To [Africans] Nigerians?}

In the early 1970s, the term Diaspora was entirely assigned as a descriptive nomenclature for persons of Jewish descent and as Safran (1991) argued, the term appeared only once or twice in dissertations at this time. By the 1980s this number had increased to thirteen times and in 2001 to approximately 130 times, with no end in sight for its burgeoning application in intellectual, cultural and political agendas (Brubaker, 2005). Diasporas are the exemplary communities of the transnational movement, and also, that the term that once described Jewish, Greek, and Armenian dispersion now shares meanings with a larger semantic domain that includes words like immigrant, expatriate, refugee, guest-worker, exile community, overseas community, ethnic community (Khachig Tololyan as cited in Clifford 1994, p. 303). Using the Jewish Diaspora paradigmatically, other Diasporas, that includes but is not limited to Palestinians, Lebanese, Indians, Chinese, and Igbo [Biafrans], Nigerians of Nomadic ethnicities began to emerge as Sheffer (2003) argues. In recent times, the term Diaspora appears to be somewhat giving way to a less emotive experience such as with the Jews and Armenians (Anderson, 1998), with terms that include 'long distance nationalists,' transmigrants (Glick, Basch, and Blanc-Szanton (1995), "immigrant, expatriate, refugee, guest-worker, exile community, overseas community, ethnic community" (Tololyan, 1991, p. 4).

Diasporas share common features of dispersal from an original homeland, often traumatically, to two or more foreign regions. In the case of Nigerians, the issue of the Nigerian Civil War or Nigerian/Biafra War, the spate of military interregna, civil unrests, religious riots-from Maitatsine-1980 to Boko Haram-2009 (Adesoji, 2011; Yusuf, 2009) and political assassinations and conflicts, a failed economy and failing state, and other intractable problems promoted large-scale movements of the intellectuals and others. These exiles became Diasporic and rightly so (Huntington, 1995), because they could not return to their putative homeland, for real or imagined reasons. Therefore, their concept of Diaspora has become firmly rooted (Brubaker, 2005) in their yearning for an increasingly miraging "homeland" (Safran (1991).

\section{Methodology}

This study represents an expansion or longitudinization of a previous study conducted by the same researcher on Diasporic bereavement. Therefore, and because the current study deals with a Nigerian Diasporic issue that encompasses and transcends that of a more limited Diasporic bereavement discourse, it was apt that the participants for that study be provided the opportunity to continue their prior narratives and lived experience within a wider dimension. The methodological context was ethnography, which is a basic tenet of social research, as Agar (1996) and Hammersley and Atkinson (1995) posit. It deals with the concept of a researcher in ethnography collecting data of a phenomenological nature, which were the result of lengthy covert or overt 
participant and sometimes non-participant observation (Wright, 2003; Hammersley, 2000). Most ethnographic data are collected by the process of phenomenological interviews, identified by Spradley (1980) as "a series of friendly conversations into which the researcher slowly introduces new elements to assist informants to respond as informants" (p.58). Using this method, the researcher digs into how the participants have experienced a phenomenon, as well as what meanings they assign or attach to the event, and then render them for an unembellished interpretation (Creswell, 1998).

There were 85 randomly selected participants in the study, with an addition of 15 others who comprised members of a focus group. 60 of them were drawn from the Nigerian communities resident in large urban areas of North America-Chicago, Texas [mainly Houston and Dallas-largest Nigerian community in the US], New York [second largest Nigerian community], New Jersey, and Washington, DC, all in the United States. This pool of participants from the US was complemented by 25 Diasporic Nigerian participants from Toronto, Montreal and Ottawa. The choice of the aforementioned cities is informed by the largest number of Diasporic Nigerians resident here. The United States has the largest number of Nigerians in the world besides Nigeria itself. According to the Encyclopedia of Immigration (2011) the number one source for West African immigrants to the United States is Nigeria. In the case of Canada, it is only second to Ghana, and in this, the U.S. Census data of 2000 and Canadian census data of 2001 stated that 165,481 Americans and 9,530 Canadians claimed Nigerian origins. To this extent, the study on the Nigerian Diaspora using these cities as the prism for viewing Diasporic Transnationalism could not have been more fitted.

The researcher conducted 50 face-to-face interviews, 20 telephone interviews and 15 Skype interviews for a total of 85 . In light of this study comprising the ethnographic method, the researcher gathered information through a review of literature, participant and non-participant observation, all of which was triangulated through the use of semi-structured interviews. All the interviews were tape-recorded and lasted anywhere between 1.5 to 2 hours. At the onset of the inquiry, the participants received consent forms which they read at their convenience, agreed to participate and signed the forms to seal their consent.

\section{Emergent Themes}

There were several themes that emerged from the interviews with the Diasporic Nigerians. However, we sieved through a rather comprehensive number of themes to arrive at the following:

Why Are Nigerians Ambivalent Over the Construction of Sustainable Diaspora Home?; Why Diasporic Nigerians Want to Go "Home"-myth of a putative homeland, home-based family pressure, culture-including filial piety, , funeral rites and ancestral burial, state-of-the-Art Mansions As Funeral Parlors; Why Diasporic Nigerians May Never Return "Home"-Healthcare and well-being, safety and security, lack of infrastructure, systemic and bureaucratic malaise, Diasporic family and dependent children; Other Reasons-Research Findings-2005-2007.

\section{Discussion}

\subsection{How did we get here?}

The entity that we refer to as Nigeria today was the result of the Amalgamation in 1914 of the Northern and Southern Protectorates into a single entity called Nigeria. Prior to this was $19^{\text {th }}$ century partitioning of Africa during the Berlin Conference of 1884-1885, among European imperialist nations, during which the entity we currently know as Nigeria was bequeathed to Britain (Nwankwo, 1998; Okpu, 1977; Nwankwo, 1970). British Imperialism in Nigeria and the West African sub-region meant that there would be a paternal relationship between England and Nigerians, with the former acting as the father proxy. To this extent, the quest for Western-type of Education-In search of the "Golden Fleece" or Whiteman's Knowledge necessitated Nigerians' sojourn to England to obtain their education and skills training.

\subsection{Interminable spate of Military interregna}

Significant Diasporic movements by Nigerians to England did not however occur until the 1960 independence 
from Britain, when the new elite began journeying to England, first as a rite of passage in the existing colonial/vassal "nuptial", and later, administrative, educational matters and pursuit of enterprise. Ogbuagu (2012); Mberu (2010) state that there was an expectation that those who sojourned to England at the time or any other to return to Nigeria on the completion of their studies to apply those valuable skills learned abroad to the local development. While a few returned and some promptly landed excellent positions in the Civil Service and private enterprise, especially with the discovery of large deposits of petroleum in Nigeria, most did not. With time, other Nigerians began migrating for the same educational, business and other purposes to the United States and other European nations. Furthermore, an increase in the spate of migration became inevitable with ethnic, religious (Adesoji, 2011) and political tensions across the Nigerian landscape. This cohort, fearing a tenuous relationship between the government and those in power and the citizenry, made deliberate decisions, to remain overseas longer, or in a lot of cases not to return to Nigeria.

To this extent, by 1978 (Mberu, 2010) the ethos of a well-orchestrated professional migration became the rule rather than the exception. The outcome was that an estimated 30,000 Nigerian graduates from the United Kingdom concluded their studies and chose to remain in that country. Another 2,000 who sojourned to the United States chose to stay put. In light of this, by 1984, as Afoloyan (1988) supplied, approximately, 10,000 highly skilled Nigerians were not only resident in the United States, but had decided to remain there. The emigration coup de grace was supplied by the fallacy and subterfuge of Ibrahim Babangida's Junta [1985-1993] "Structural Adjustment Program." Through this well-orchestrated shenanigan, Nigerians were further "shakendown" and became the poorer for it, forcing many Nigerian professionals to troop out of the country (Ajibewa $\&$ Akinrinade, 2003).

The "Structural Adjustment Program" (Nwagbara, 2011) was enacted in an agreement with the IMF for a loan in the mid-1980s, which included the devaluation of the Nigerian currency, the Naira, at the time exchanging for 65 cents to the US dollar. What this meant was that wages fell and were no longer competitive, while the working conditions for a large number of skilled professionals became untenable, forcing further exodus of Nigerians to other parts of the world. With the continued desperation in Nigeria, many less-skilled Nigerians joined the fray. This and the growth of globalization resulted in mass exit of this younger generation to Germany, France, Belgium, Italy, Spain, Ireland, the Netherlands and the Gulf States by the 2000s. As we document this, yet another set of skilled migrants, represented by doctors and Nurses is leaving in their droves to the Gulf States and United States, where their skills are said to be handsomely rewarded. This group became the Nigerian Diaspora as we shall see in the course of the study. At the last count, Singer (as cited in Nworah, 2007), states that there are approximately 15 million Nigerians, comprising 1 in 10 Nigerians who call Diasporic destinations home. As stated earlier, Nigerian Diasporic and emigration events or liaisons followed three major phases. Perhaps, in the course of time and with the changing face of globalization, there may yet emerge other phases of Nigerian emigration to the west and other nations of the world.

\subsection{Nigerians \& Diasporic Liaison-1950s-1970s}

I had intimated at the onset of this study that the initial rationale for sojourn to Europe and North America was to capture the "Golden Fleece." This concept is embedded in Western Education and technology [In Greek mythology the Golden Fleece is the fleece of the winged ram Chrysomallos. In this tale Jason and his band of Argonauts, set out on a quest for the Fleece in order to place Jason rightfully on the throne of Iolcus in Thessaly (Hunter, 1997). The expansion from a homeland was predicated on search for work, in pursuit of trade or to further colonial ambitions. Those going overseas for study had assigned expectations that were implicit. They were admonished by family members, sponsors-usually churches and religious institutions, etc. to return to Nigeria on completing their studies to help build the nation, and fill the vacuum left by the departing British Imperialists. The next Diasporic epoch was between 1970-2008.

\subsection{Nigerians \& Post-Diasporic Liaison-1970s-2008-}

\subsection{Current Migration Rationale to Europe and N. America}

During this epoch, the quest for the "Golden Fleece" had not completely been erased as a rationale for sojourn, 
although it had become somewhat subsumed in all other era prescribed rationales. Findings by USAID (2007) also show that some of the Nigerian professionals left Nigeria as economic immigrants rather than as political refugees. Those who were sojourning quested for the possibility of a distinctive, yet creative and enriching life in host countries with a tolerance for pluralism. While this appears to be the case, as we shall see, in the case of many Nigerian professionals in the Diaspora living in North America and Europe, it is not the same for some others even in these same countries and in some other countries. Truth be told that professional success in the Diaspora is not absolute. However the 'failures' are presumed temporary, as they believe in the open and sustained opportunity to operate and function in a professional environment, something they could not accomplish while in Nigeria. Despite the lack of success on the part of some Nigerians in the Diaspora, there exists a sustainable and clear line of career progression in these developed countries, which will continue to give them hope and the belief that they could still succeed. Ajibewa \& Akinrinade (2003) opined that the search for educational and training opportunities by many young people outside Nigeria is consequent upon the destruction of the educational systems in many African nations and communities. Harris (as cited in Ajibewa \& Akinrinade, 2003) asserts that "increased migration is inevitable in an integrating world economy, that is increasingly characterized by widening inequalities between the rich and poor nations" (p.3).

\section{Who Are the Nigerian Diaspora?}

Diasporic Nigerians are those who left Nigeria for any reason and have taken up residence outside of Nigeria, without any immediate plan to return to Nigeria to reside. Diasporic Nigerians are dispersed all over the globe. American Christian Science Monitor (2002) estimates that 15 million Nigerians (more than 1 in 10 Nigerians) live in the Diaspora. According to the United Nations, there are approximately 1.1 million Nigerians living outside their home country, representing 0.84 percent of the Nigerian population. This figure plainly falls short of the reality since it is impossible to accurately calculate the number of Nigerians in the Diaspora. In the West African sub-region alone, there is a substantial migration trend, with Ghana being host to at least half a million Nigerians (Orozco 2006). Another location is post-Apartheid South Africa, where the migrational trend over a ten-year period, makes the subscription to the official number of Nigerians here put at 20,000 challenging to agree with.

In the United States, a single transfer company reports processing 125,000 transfers monthly to Nigeria, a figure that is nearly identical to the U.S. Census and U.N. estimates $(134,940)$ of Nigerians in the U.S. Another report argues that there are half a million Nigerians in England and reports that one-third of West Africans are living outside their country (Black, Ammassari, Mouillesseaux, and Rjkotia, 2004). Adebayo (2010) puts the figure of Diasporic Nigerians at 20 million, with approximately 3.4 million residing in the United States alone (Akinrinade and Ogen, 2011). The fact of the matter is that like citizens of other countries, there is a large number of undocumented Nigerians throughout the world, with the concomitant that we may never know the actual number of Diasporic Nigerians, no matter the steps that we or the host countries take to collect a census of them. The tables below attempt to show some of the regions of the world, including Africa where Nigerians reside and many call home. Noteworthy is that this list fails to exhaust the population of Diasporic Nigerians. What it attempts to provide is only an estimate which rather than being static, fluctuates each day as more and more Nigerians leave.

\subsection{Where are Diasporic Nigerians Located by world regions?}

Table 1

\begin{tabular}{|l|c|c|}
\hline Region & Population & $\begin{array}{c}\text { Percentage of the } \\
\text { general population }\end{array}$ \\
\hline East Asia and Pacific & $37,878.53$ & N/A \\
\hline Europe and Central Asia & $954,154.59$ & N/A \\
\hline Latin America and Caribbean & $10,950.85$ & N/A \\
\hline Middle East and North Africa & $145,703.47$ & N/A \\
\hline
\end{tabular}




\begin{tabular}{|l|c|c|}
\hline North America & $763,401.14$ & N/A \\
\hline South Asia & $61,776.72$ & N/A \\
\hline Sub-Saharan Africa [South Africa] & $3,197,540.02$ & N/A \\
\hline
\end{tabular}

Grand Total 5,171,405.32 approx.

Estimated Nigerian migrant populations, from Global Migrant Origin Database.

Source: United States Agency for International Development, USAID, 2007.

7.2. Where are Diasporic Nigerians located by country in Africa?

\section{Table 2.}

\begin{tabular}{|l|c|c|}
\hline Country & Population & $\begin{array}{c}\text { Percentage of the } \\
\text { general population }\end{array}$ \\
\hline Sudan & $247,420-1,354,809$ & $23.76 \%$ \\
\hline Cameroon & $87,352478,317$ & $8.39 \%$ \\
\hline Ghana & $53,486292,876$ & $5.14 \%$ \\
\hline Niger & $41,379226,581$ & $3.97 \%$ \\
\hline Benin & $29,911163,785$ & $2.87 \%$ \\
\hline Burkina Faso & $26,572145,502$ & $2.55 \%$ \\
\hline Guinea & $25,885141,740$ & $2.49 \%$ \\
\hline Kenya & $25,853141,564$ & $2.48 \%$ \\
\hline Togo & $18,695102,369$ & $1.80 \%$ \\
\hline Gabon & $14,79080,986$ & $1.42 \%$ \\
\hline Other & $184,062889,571$ & $17.68 \%$ \\
\hline
\end{tabular}

Source: Global Migrant Origin Database, Development Research Centre on Migration, Globalisation and Poverty (Migration DRC). March 2007, Version IV.

\section{Why Are Nigerians Ambivalent over the Construction of Sustainable Diasporic Home?}

\subsection{Impacts [PTSD] of the Nigerian/Biafra War-1967-1970}

It would appear that one of the many reasons that Nigerians feel an ambivalence over the construction of sustainable Diasporic "home" is contingent on a troubled relationship with host societies, suggesting lack of acceptance at the least or the possibility that another calamity might befall the group. Nigerians from the former enclave of Biafra exhibit this apprehension more than others (Achebe as cited in The Guardian, 2012). To illustrate this, Nigerians from the former Eastern Nigeria [Biafra] have been known to be fierce entrepreneurs, a state of being that has seen them travel beyond their own ethnic, cultural and religious boundaries to conduct business, mainly commodities trading. Within Nigeria, a lot of South easterners have populated the south western cities of Lagos, Ibadan and Abeokuta. In the North, you will find them in Kano, Kaduna, Zaria, Maiduguri, Sokoto and Abuja. Prior to the Nigerian Civil war, these Easterners as they were referred to, called the places of sojourn home. They not only conducted business here, but they built homes where they resided and many more for income purposes. When the pogrom of 1996, a prototype of Ethnic Cleansing began in the West and North of Nigeria, the Easterners, comprising the dominant ethnic group, Igbo were targeted and massacred in their thousands. Consequently, the survivors repatriated back to their homeland, but lost everything, including investments, movable and immovable property.

Those who survived had to begin life afresh, with nothing but the shirts on their back and this was hard and continues to haunt them today. To this extent, those from the former enclave of Biafra became refugees 
during the Civil War and after this war, have remained on the margin within government and entrepreneurial dispensation. While in the Diaspora, this group of Nigerians has carried with them all the PTSD and trauma of dispossession into their Diasporic residence and are perpetually frightful of losing out once again should something untoward happen to them in their host countries. In light of this, those, especially the Igbo from the former Eastern Nigeria have a hard time "settling down" in the host countries, where some have ironically been resident for over 40 years.

\subsection{Resurgence of White Supremacy and Neo-Nazism in host countries}

Freedom of speech and expression is enshrined in the constitutions of some of the nations of the west, and held as an inalienable right. Contingent upon this, some of their citizens from the majority and dominant population have taken this constitutional rights and freedom a little too far, in light of the resurgence since the 1970s of White Supremacists, Fascists and Neo-Nazi Organizations, which populations are fast growing, especially due to increasing immigration trends and the fact of globalization (Bello, 2008). The rise of xenophobia and nationalistic thinking amongst the citizens of the host countries of Diasporic Nigerians presents another rationale for not "rooting down" in host countries. These Neo-Nazi organizations express extreme xenophobic fervor and continue to demand the repatriation of Blacks, Jews and others who they consider as non-White. Again, those Nigerians who have experienced the trauma of pogrom and ethnic hate readily relate to this threat, take them quite seriously, therefore consciously or unconsciously maintain a fleeting relationship with their host countries. In this way, they do not see themselves as a part of the society where they have lived, worked and contributed for many years. They see themselves as outsiders, and often there are events, such as the 9/11 and the subsequent social policies by the United States government (Ogbuagu, 2013) that continue to remind them that they belong elsewhere and are sometimes really not welcome.

\subsection{Institutional and systemic racism}

The other reason why Nigerians show ambivalence over the construction of a sustainable Diasporic home is related to Institutional and systemic racism and the existence of the glass ceiling which they insist hinder their professional growth. Consequently "Home Coming" is currently gaining currency amongst the Nigerian professionals in the Diaspora. To understand this phenomenon, it would be important to stray into some details, which expatiation may assist articulate its impact on how Diasporic Nigerians feel, think and subsequently act to try and surmount it. What is Institutional racism?

\subsubsection{What is Institutional or systemic racism and how is it reproduced and perpetuated?}

It is composed of social, political, educational, and economic structures Marger (2003); Mann (1993 that are designed to benefit one group, while the same structure disenfranchises others. The issue of institutional racism presents as the prejudicial and discriminatory practices that the majority or dominant culture applies in the socio-economic and political spheres, which then allows them to control, sustain this control and reproduce it, while it dispossess those from non-dominant cultures. Institutional racism applies power and control through those at the institutional sub and superstructure to enact and execute policies and laws (Feagin, 2006) that while they promote their own interests, sustain others not like them on the margins. Jones (1997) agrees with this assertion, adding that the emasculatory practices are operationalized against Black and Hispanic families through the juvenile and criminal justice systems, having designs that trap and saturate itself with the non-white ethnic groups. This dispensation becomes much more glaring when the frequency of reporting and retention of reports against Black and Hispanic families, shown as higher, are juxtaposed with those of White families, even when the same behaviors have been controlled for.

Nigerians both in the country and outside of it are subjects of British imperialism over many decades, when they were only qualified as hewers of wood and drawers of water, therefore understand the discourses of exclusion. They therefore understand racism and "otherness", which have now become insidious following the enactment of "Affirmative Action" and other equity policies designed to promote social justice. However insidious racism and racialization may present itself, Nigerians in the Diaspora are still able to frame its existence, 
operation and reproduction in the labor market relations that are dominated by Whites, who constitute the largest percentage of labor employers (Ogbuagu, 2012). In institutional racism, as the Nigerians in this study opined, Whites as the dominant group apply some artificial theoretical assumptions (Kluegel, 1990;Kluegel and Smith, 1982, 1986), including capital theory, the Marxist theory, labor market segmentation theories, and the vertical mosaic thesis (Mensah, 2002; Porter, 1965) to discriminate against and exclude Blacks, of which Nigerians are a part. The respondents in this study stated that although Nigerians are disproportionately well educated (Casimir, 2008) even superior in their chosen fields, the fact that they have been lumped with other Blacks and minorities, means that they will be entrenched in any and all subjectivities that have been used to define that group. Whites, as Kluegel (1990)Kluegel and Smith (1986) argued, also maintain and reproduce institutional racism in the labor market through "networking" [actually nepotism] by families, dynasties, schools and educational cohorts, in addition to the scapegoating, oppression and segregation which Whites use to exploit Blacks and other minorities in the labor force (Das Gupta, 1996).

For Das Gupta, the issue of racism is not an accident or borne out of inadvertence. It is a calculated, highly organized and orchestrated effort to sustain a pool of cheap, expendable labor, in the "McJob" and other deadend, secondary labor sectors (Mensah, 2002) through promoting, sustaining and perpetuating the powerlessness of Blacks and minority groups on the labor force. On the other hand, Whites and members of the dominant group occupy the primary labor sector commanding specialization, higher wages, generous pensions, mobility, greater unionization, and other fringe benefits. Subsequently, this powerlessness status assigned to Blacks and other minorities in the work force translates into the maximization and appropriation of surplus capital for the dominant group. The Nigerians in this study declared that many of them are serving under Whites as their managers and bosses, who have far less education and qualification than they do. Some are employed in jobs for which they are overqualified. These Nigerians all attended school and obtained their degrees in North America, and some of them studied at the so-called Ivy League institutions. What this means is that the attainment of a sound higher educational status (Torczyner \& Springer, 2001) does not necessarily translate into a commensurate upper mobility for Blacks, including Nigerians. They stated that this would not be the case were they residing and working in Nigeria.

The Nigerian respondents in the study spoke to the issue of White, male privilege and its concomitant for them as marginalization, and the fulcrum of their desire to be homebound. This point appears to be well taken by Dines (1994); Sleeter (1994); Thomas (1994); McIntosh (1990) who argue that the mechanism of White, male privilege and the dominance of power in society, by Whites, renders the Whiteness and especially, the privilege assigned by Whiteness invisible, even as it progressively and relentlessly erodes with impunity the privileges of non-Whites. They argue further that Whiteness and its conferment of privilege is normalized, even seen as ataken-for granted entity by those whose pedigree is White. Joining the fray, Hooks (1992); Dyer (1988) argue for Whiteness as an endeavor that was pursued and embraced aggressively in popular culture. This aggressive pursuit was designed to rearticulate, reengineer and promote individual and esprit de corps among those of the European and Anglo-Saxon descent, who perceive themselves as "sieged" by minorities and ethnic individuals. In this arrangement, the dominant culture constructs Whiteness as invisible, while paradoxically seeing itself and forces others to see it as transparent. White invisibility then assumes a paradoxical interpretation, on account of the absence of recognition by White people that the main reason that they are privileged is because they are White.

Dei (1996) supplied:

...there are enormous social, political and economic benefits that historically have accrued, and continue to accrue, to certain individuals in society due to the dominance of white, (male) power. It is how economic, political and social power was amassed historically and utilized by certain individuals and groups in society to deny and denigrate the humanity of others that has given rise to the anti-racism struggle. Anti-racism interrogates White privilege and the ideology that maintains and supports both Whiteness as a social identity and the dominant institutions of society (p.28).

Bolaria and Li (1988b); Walker (1980) opine that Blacks in North America, in light of their "entrance status in the Vertical Mosaic treatise (Porter, 1965) and elsewhere are disproportionately exploited and discriminated against in employment, education, housing and social services. As the custodian of individual and group rights, the Canadian government was apprised and admitted that institutional racism and ways it reproduces itself is by 
leaps and bounds more damaging than those meted at the individual level. The Federal government, after centuries of participation and acquiescence to the emasculation of Blacks and other ethnic minorities in the labor market and other areas, tried to stem this tide by enacting the Employment Equity Act (Samuel and Karam, 2000). This Act was purposed to create, as well as promote a diversified work environment that mirrors the general population.

Although this attempt was viewed as somewhat genuine, institutional racism promptly infiltrated the arrangement, creating a work environment of dead-end, "McJobs" that is littered with the "carcass" of designated groups (O'Connor, 1999). Henry, Tator, Mattis and Reese (2006); Boyko (1998) all agree that institutional discrimination emanates from systemic hiring, promotion and dismissal practices that prima facie present as neutral, but are fixated on stymying the growth and upward mobility and sustenance of designated groups represented by Blacks and other minority and disadvantaged groups. Ojo-Ade (2004) is vehement that, "mainstream America does not want success for any attempt at re-humanization of Blacks and Africa, nor does it support the rehabilitation of African cultures" (p.6). The excerpts below represent what the Nigerian respondents said about institutional and other forms of racism.

If a White man...if it took a little effort for a White man to attain or achieve something, we would have to put ten times that effort, in order to be recognized...

Because, I mean, I've been in Canada, for a reasonable number of years and I experience a lot, both when I was in school, and in the labor force. Trying to get a job...okay, I will go back, I will just give you and example. When I was at Concordia, a company advertised that they needed a lab. technician. They didn't need experienced lab technician. During that time, I was in my first year and I qualified for that job. I remember very well, because all the requirements they have asked for, I had it. When I went for the interview; first I, yeah, the school called the guy, that they found somebody. Then he arranged what day I should come. When I got there, well, it wasn't...call it an interview, but it wasn't an interview, because they made the school choose the student that was most qualified. When I got there, you could see the shock in the guy's face that they sent a Black person. This guy hammered me all kinds of questions, both relevant and irrelevant, stupid questions. It had nothing to do with the academic work, you know? Just asking stupid questions; you could just see, he was very uncomfortable. He told me okay, he will look into it. Did you know that he hand-picked a drop-out student from high school, trained him, yeah, instead of giving me the job? I mean, the list could go from here to tomorrow (Stan-name changed to protect identity of respondent).

Paul, [not real name] a Community leader, made the same observation about Canadian race-based inequities and the advantages of a Black youth having a successful educational outcome.

Now, even though they changed in that way here, there's something still there; their color is still there, okay? How can they deal with their color? Accent wise, they've dealt with it, but the other side, they cannot deal with that. So they got a problem there... Yeah, they cannot erase that. So, now they call somebody for job now, they say, oh yeah, the job is available. But as soon as the kid arrive now, they see their color now, and it's okay, I'll call you back later on

Now, it's something that we're hearing today, now, if you're a Quebecois, you can have any job you want, with your secondary school degree, diploma. But as an African or a Nigerian, it is difficult for you to find this kind of job, with your secondary school diploma...By the White kid. He would be given by his uncle; somebody will give him something. Maybe his father is rich and will give him something. You do not have that advantage. So the best thing is for you to go to school, so you can compete with them. So, this is one of the things, the problems we have with education. Why should you go to school and others are not going to school, when education is not valued in the Quebec society? So, what we say now is do well so, and you can compete with them, because if you study now, if you have education, you can never lose, it will be an advantage to you.

Dan, a Community leader in his own argument stated:

Most of these kids are in Toronto but their parents live in Montreal and they get their education in Montréal but they are not here. So, is it maybe because of jobs? If I come hard on it I will call it discrimination, because er, if these kids cannot find their jobs definitely they have to leave their parents. And go to where they will be where they will be understood or whatever. 
One of the Nigerian youth born in North America had this to say:

My Dad has a PhD...he...he can be a doctor. When he came here, he can't even...like I heard on the radio, um they're talking about how um professional Black...um... what's the word am looking for...?...Professionals in from the Caribbean or Africa? When they come here, they can't do anything. You know, they, they neglect Black people. My Dad went from being a doctor to being a carpenter. That's not right...

\section{Why Diasporic Nigerians Want to Go "Home"}

Among Nigerians and other Diasporic persons everywhere in the world, there remains an idealization of the putative ancestral home and a collective commitment to its maintenance, restoration, safety and prosperity, even to its creation. This collective memory and myth about the homeland, including its location, history and achievements, become catalytic in the quest to return (Connor, 1986). Such findings show that Nigerian professionals have a strong "Home Coming" mentality and of patriotism. They still maintain social and religious ties with their fellow Nigerian Diasporas [Nigerian/Canadian Association, Nigerians in the US, Nigerians in the UK, Ukraine, China, Pakistan, India, Finland, etc. and also with relatives and friends back in Nigeria. In the case of the so-called 1.5 generation represented by children of Diasporic immigrants, there is a common perception that many Nigerian children in the Diaspora today can be labeled as a lost generation as they struggle to balance their identity (Uzondu, 2012). Diaporic parents engage or at least try to engage their children, especially during the plastic, malleable years in cultural activities that show who they are, where they come from and where they want them to go. These parents live vicariously through their children, for fear that the children may be lost in a foreign land when the parents and their generation die out. In Finland, 95 percent of Nigerians have Finnish wives (Ude-Chime, n.d.), and on account of this, Nigerian parents engage their young children, especially the males in many and often intense cultural activities throughout the year to anchor them to their roots.

One parent participant stated:

But as our culture is, I have property at home, in Nigeria. I have brothers and sisters in Nigeria, and I expect my son to inherit whatever I have in Nigeria, and to live in Nigeria, if possible. That's that's the biggest issue. ...the boy's name remains stable model and will continue to keep the family...[inaudible]...as long as, so... But in my own culture, the women cannot inherit anything I have at home, no matter; the will cannot override it. The culture speaks first before the will. And the son, and my son, is in control of that. Nobody else can go there. And I have a lot of investments in Nigeria, which I would like him to...that's why I am going try to encourage him as much as I can encourage him to make sure that these things are not lost if am not here...

Akin to this is the Jewish Diaspora's idealization of a putative ancestral home, Israel, even for those Jews, born elsewhere and who have never been to Israel. Findings from this study, as well as the researcher participant observation and experience as a Diasporic Nigerian show that Nigerian professionals in the Diaspora still contribute in different ways, individually and collectively towards Nigeria's socio-economic development. One instance is the Federal government of Nigeria's establishment of the Nigerians In Diaspora Organization- NIDO, created to engender matrifocality amongst Nigerians living overseas. The scope of this study precludes an indepth analysis of NIDO.

\subsection{Death, funeral rites and interment}

Ogbuagu (2011) informed that among the Igbo of the former Eastern Region and defunct Biafra, there is a cultural expectation that one's bones must be interred with his ancestors. Without post-mortem repatriation, the deceased is perceived as doubly "lost" or an Efulefu. It is traditionally shameful for "the head [remains] of "Nwadi Ala" [A natural born son] to be lost in a foreign land (Gugler, 2002). Culturally, it is a shame for a family not to repatriate its deceased from a foreign land. The participants in the study were quick to provide an analogy with American Marines in Vietnam or any other conflict, who must be located, at any expense, even the loss of further marines just so the body is recovered and repatriated to America.

So, the expectation by every Diasporic male is to build and maintain a decent home in Nigeria and visit frequently. This home also doubles as a funeral parlor, since commercial funeral homes are still a novelty in most 
Nigerian communities. To this extent many Nigerians have gone to great expense to erect impressive, state-ofthe art mansions (Osili, 2004) in Nigeria, which they visit infrequently, because the primary reason for its construction is to be laid in state and in style there for all to view prior to internment. Again, internment is never in a cemetery, a rare burial place for Nigerians, but right at the entrance of their well-appointed and fortified mansions. To accomplish this, as Ogbuagu continued, Diasporic Nigerians take out large insurance policies; join all sorts of clubs, town meetings and self-help organizations, all of which is hoped to provide the often prohibitive finances required for post-mortem repatriation and grandiose funeral in their Nigerian homestead. Although most Nigerians would be quick to argue that they are erecting homes in Nigeria for their retirement, and comfort when they visit, it is rare to see any Diasporic Nigerian retire in the west and return to Nigeria to reside on any permanent basis. Most often "return" in caskets in the cargo bay of commercial jet liners.

\subsection{Other Reasons for wishing to return home-mal-adaptation to North American systems}

\subsubsection{The "too late" syndrome and Internalization of "Outsiderness"}

There is a finding (Ogbuagu, 2007) that a large number of Diasporic Nigerians would rather return to Nigeria due to the internalization of a negative lived experience in the Diaspora-racism, unemployment, cultural deracination, and others, all of which endow them with a sense of hopelessness. The only way they presume to remedy this is by returning to their homeland, where they feel that they rightly belong. Findings from this research showed that some of these Diasporic Nigerians have unsuccessfully struggled with the integration of new technology, specialization and retraining, or failed to explore other avenues for integrating into the Diasporic labor markets. In light of this, the study found that this group of Diasporic Nigerians, most of whom arrived in the west when the vogue was completing studies and returning home, appear to, and has acquiesced to defeat in the Diaspora, on account of being trapped in that dream of one day returning to Nigeria. On account of having planted their cultural and psychological roots in Nigeria, they perpetually view themselves as outsiders, even while continuing to physically reside in the host countries. What this fixation does to them is place limits on the pursuit and attainment of any meaningful integration in their Diasporic residence. The same group of Nigerians submits to the "Too late" syndrome, by engaging in parental altruistic denial of their own aspirations in favor of heavy investment in [their children] the future generation.

\section{Indices for Constructing \& Maintaining "Home" In Nigeria}

\subsection{Familial [Consanguineal, Conjugality] Ties}

10.2. Remnants of family members in Nigeria-parents [surviving or deceased], siblings, in-laws, extended family-

Most Diasporic Nigerians have family members and familial ties back in Nigeria. These ties are represented by consanguineal ties-parents [if alive] spouses, children, siblings, and a large pool of extended family members, and conjugality ties-in-laws. Cultural norms and filial piety (Ogbuagu, 2011) has significant impact on how these ties are viewed and maintained in perpetuity by all. These variables also account for why Diasporic Nigerians maintain consanguineal and conjugality ties to their units in Nigeria. During the 1950s and earlier, when sojourn to the west was still a novelty, the concept of miscegenation, which was propagated by Whites in the west as a race discourse, applied also to family members of the "Golden Fleece" seekers from Africa. Usually, there was a send-off party organized by the family and sometimes, the whole village, for it may be the first time that any of their sons or daughters would be going overseas. Sojourners to Europe and America [mainly for studies] constructed and had "home" constructed for them in Nigeria by the following admonitions:

"Do not marry a White Woman-They have very slim waistlines, therefore may not bear children."

$$
\text { Or }
$$

"The White Woman is not fecund"-An assumption derived from the usually [culturally relevant] limited family size of Europeans

"We have "Okonkwo's daughter waiting for you when you return"

"Our home is falling down, or our home is no longer fit for habitation and it is waiting for your return. If you marry there [pointing to whatever the direction they believe the Whiteman resides] you will not come back 
and we shall be the laughing stock of the village."

With these instructions, the intending Diasporan becomes well aware of expectations and why he must return home on completion of his studies or conduct of business. Again, the concept of family honor when the sojourner returns after studies, and conversely of family shame if they fail to return on completion of studies remains implanted in the intellectual and psychical being of the Diasporic Nigerian (Levitt, 2002a). The Diasporic Nigerian is viewed as the "savior" for the family because he or she is going overseas, where things are surely better than home and even the concept of money growing on trees become a truism rather than a cliché. In recent times the almighty Greenback, the Pound Sterling and the Euro have entered the list of expected transfers medium by Diasporic Nigerians to family members in Nigeria. The following examines such financial transfers as one way of constructing "home' for Nigerians in the Diaspora.

\subsection{Promoting and sustaining ties to the homeland through the supremacy of Money Transfer Organizations-} Western Union Money, Money Gram and others

One of the more important Diasporic umbilicus (Guarnizo, 2003; Hondagneu-Sotelo and Avila, 2003; Jones, 2002) to the homeland and consanguineal ties is the remittance of money and other financial products and lifelines to family members (Ratha and Xu, 2007). In these, the Money Transfer Organizations-Western Union, Money Gram, Vigo, LCC, Munditransfers and a host of other money transfer gnomes, become the medium of this transaction, with the first two listed having supremacy over all others. Most recipients of these pecuniary transfers understand the codes and have come to expect them as a sine qua non amongst their Diasporic family members. This is not to say that there are no other means of sending money (Hernandez-Coss, and Bun, 2006) to the homeland, as most of the money sent to the homeland is through human couriers who are visiting the homeland from Diasporic locations across the globe. These monies remitted to the homeland, according to (Ogbu, 2008) are applied to food, education, health needs of family members, real estate investments and transportation. Additionally and more poignantly, is the fact that remittances to countries such as Ghana, the Philippines and Kenya account for approximately 10 percent of the Gross Domestic Product-GDP. As well, the remittances provide the major economic support (de Haas, Hein, 2005) for these developing countries, without which some of them will be on the brink if not collapse. Dr. Shamsuddeen, Usman, the 2006 Nigerian Finance minister stated that Diasporic Nigerians' remittances to the homeland doubled from a previous count of $\$ 10.5$ billion in 2006 to $\$ 17.9$ billion in 2007 (Ogbu, 2007). Ogbu surmised that the rise represented a significant increase in the amount of remittances in the last two years, with a comparison figure in 2005 standing at $\$ 6.5$ billion (Aderinokun, as cited in Mberu, 2010). Table 3 shows the MTOs and the percentages of pecuniary transfers by each.

10.4. Major Money Transfer Organizations-MTO, locations and their percentages of transfer stranglehold

Table 3.

\begin{tabular}{|l|c|l|}
\hline Money Transfer Organization-MTO & $\begin{array}{c}\text { Percentage of } \\
\text { Transfer holding }\end{array}$ & Country/Region Based \\
\hline Western Union Company & 78.26 & Englewood, Colorado, United States \\
\hline MoneyGram & 15.38 & Dallas, TX. United States \\
\hline Envio De Valores La Nacional & 2.34 & New York, New York, USA \\
\hline Cam & 2.01 & NY \& Florida, USA \\
\hline Citibank [Citigroup] & 0.67 & New York, USA \\
\hline Bank & 0.33 & N/A \\
\hline Bank To Bank & 0.33 & N/A \\
\hline Hand By Hand & 0.33 & N/A \\
\hline Vigo [subsidiary of Western Union Company] & 0.33 & New York, New York \\
\hline
\end{tabular}

Total $100 \%$

Source: Survey of remittance senders United States Agency for International Development, USAID, 2007. 


\subsection{Financial Remittances in 2006}

The following is a conservative rendition of monetary transfers to Nigeria in 2006

A World Bank report about the U.K.-Nigeria corridor claims from interviews with money transfer organizations (MTOs) that there are five million Nigerians in the United States remitting the following monetary products (Hernández-Cox and Bun 2007).

\section{Table 4.}

\begin{tabular}{|l|l|l|}
\hline Region of Remittance & Percentage of Remittance & Percentage of Remittance \\
\hline East Asia and Pacific & @ 80\% Remitting $\$ 39826569.83$ & @ 70\% remitting $\$ 34848248.6$ \\
\hline Europe and Central Asia & @ 80\% remitting 1,474,896,580.72; & @ 70\% remitting = 1,290,534,508.13 \\
\hline Latin America and Caribbean & @ 80\% remitting 10,454,414.98 & @ 70\% remitting 9,198,717.10 \\
\hline Middle East and North & @ 80\% remitting 139,875,328.62 & Africa @ 70\% remitting 122,390,912.54 \\
\hline North America @ & @ 80\% remitting 1,465,730,197.24 & $70 \%$ remitting 1,282,513,922.59 \\
\hline South Asia & @ 80\% remitting 59,305,651.81 & @ 70\% 51,892,445.33 \\
\hline Sub-Saharan Africa & @ 80\% remitting 831,360,404.14 & @ 70\% remitting 727,440,353.62 \\
\hline
\end{tabular}

Grand Total @ 80\% Remitting 5,134,599,201.65; @ 70\% Remitting 4,497,749,688.27 4,200,000,000

Official World Bank Figure (2006) $=\$ 4,200,000,000$

Source: World Bank. World Development Indicators, 2006

\subsection{Demographic Profiles of Senders [From Europe \& N. America]}

- On average, Nigerian senders had lived in the United States for seven years

- The average age of senders in the survey was 36, and just under two-thirds were male

- 70 percent indicated that they were not American citizens

- Highly educated, with more than 40 percent of senders having completed high school and 50 percent having at least some college education

- Among recipients, more than 40 percent had completed some college. Personal income of senders averaged $\$ 16,000$ per year

- Close to 50 percent of respondents indicated that they made between $\$ 10,001$ and $\$ 15,000$ annually

- Household income, excluding the income of the respondent, averaged $\$ 13,500$ per year

- Approximately 60 percent of senders stated that their households made less than $\$ 10,000$

Source: Survey-United States Agency for International Development, USAID, 2007.

\subsection{Profile of recipients of the Diasporic/Transnationalist largesse}

- $\quad$ Among recipients, the mean annual income population was N197,803.75, or US\$1,583.57-

- 66 percent higher than the World Bank estimate of Nigerian gross domestic product (GDP) per capita (PPP) in 2006, which was US\$1,050 (World Bank 2007).

- Among recipients, about 20 percent had been receiving remittances for less than one year, 45 percent for one to three years, and 20 percent for three to five years

- Recipients were slightly younger than the senders, ranging from 25 to 34 years old, and over 70 percent were male. Why?

\subsection{Demographics of Recipients}

10.8.1. High incidence of male recipients 
Several possible reasons have been advanced for the high incidence of male recipients. Two reasons stand out. The first outstanding plausible reason is that there is a higher rate of male migrants or commuters than women from the rural to the urban locations. These males then pick up the remittances and return them to their ruraldwelling relatives. The other is that males are used to pick up the remittances in that they are less vulnerable than women in case of attacks against them aimed at divesting the remittance of them. The third less plausible reason is that literacy rates among males are higher than that of women in Nigeria. The ability of the males to read, write, sign their names, as well as provide answers to questions that usually arise when picking up the remittance is particularly important, and less intimidating for this demography. What fuels the remittance of such large financial capital to the homeland, one may ask?

\subsection{Senders Rationale for Saving \& Remitting Money}

- For my or children's education $56 \%$

- In case of death in the family $52 \%$

- For home improvements $47 \%$

- In case of Illness $37 \%$

- To invest in small business $34 \%$

- Birthday, Wedding, etc. $28 \%$

- For their retirement $26 \%$

- Funeral expenses and arrangement $20 \%$

Source: Surveys of remittance senders and receivers, authors' analysis (USAID, 2006).

\section{How is Diasporic Connection to the Homeland sustained?}

The study shows that with the failure of the Nigerian Telecommunication Limited-NITEL, the deregulation of the mobile phone market and the introduction of the Global System for Mobile Communication-GSM, virtually every Nigerian owns and operates at least once cellular telephone. Often there are more, and some may have as many as four "handsets" as it is popularly referred to in Nigeria (Odunfa, 2012). Why so? The bandwidth of some of the phone and providers are low and may not cover a large area, requiring that one picks up another carrier in order to remain connected to family, friends and business partners. The proliferation of state of the art cellular telephones, with text messages and the accoutrement of "flash me," means that an estimated 88 million Nigerians in 2011 own at least one cellular telephone. Harshman (2010), states that Nigeria uses six cellular telephone networks. Of these, the most popular and commonly subscribed to are MTN, Glo and AirTel (previously Zain). Etisalat, Starcomms and Visafone are the others. For cheap US calls, Starcomms and Visafone are the ones to subscribe to. To this extent, this the fastest way for Nigerians in the homeland to ascertain their sustained connection to their Diasporic relatives. Any Diasporic Nigerian can relate to the experience and the fallacy of Hilary Clinton's claim to the 3:00 am telephone call, for this is the time that homeland relatives will call you in the Diasporic location (Ogbuagu, 2011). Worse still, the Diasporic relative would have been asleep, but this is not important as the homeland relative would never leave a message [the cultural nuance is a face-to-face conversation, not a disemboweled message] and will continue to call several times until sleep becomes a thing of the past, at least for that night. If it is that important to them, and it is always urgent, sometimes, a matter more of death than life, they will resume the calls every night until they speak with the hapless relative.

The other less used but prominent mode of remaining connected to the Diasporic relative is the Internet. One drawback for its infrequent use is that it is not fast enough and the relatives from the African continent may not be instantly gratified that they have made sufficient contact with their son, daughter, uncle or aunt. And yes, they have Facebook pages too, where they feature everything about their lives and will find the Diasporic entity when they need them.

\subsection{Peer pressure [Age Grade Systems] and reference to cohort achievements in Nigeria}

The age-grade cohort system remains strong in Nigeria, especially among the Igbo of the Eastern Nigeria. Here, the age grade comprises people of the same age cohort, whose responsibilities among other things is as a 
warrior class. They are mainly young men and women, but could also be older citizens of a village or town. They settle disputes, enforce the local laws and in the days of yore, went to war to defend the village. In this regard, family members frequently invoke the achievements of one's age cohort in the homeland (Chukwuezi, 2001) as a reason to complete a house, engage in a project, send money, put another family member through school and other responsibilities. They usually point to one's age cohort and state "Have you not seen that your age mate, Okafor's son, has completed the building of his and parent's house" or when they are really upset, they will state"are you not ashamed that Okonkwo's son, your age mate is now married and has children and you are in the land of the Whiteman doing what?" These pressures are designed to remind the Diasporic family member of age or cohort-appropriate milestones (Ong, 1999) that need to be matched or even beat. The issue of cohort achievements and elitism has also largely promoted the saturation of the homeland with chiefs, High Chiefs, Super High Chiefs, Ultimate High Chiefs, Traditional Rulers [Eze] and a host of other appellations designed to express a higher class and social order. Sometimes, Traditional Rulers will invite a Diasporic Nigerian to come home (Levitt, 2004) and be invested with a title, sometimes after the prospective chief parts with some of his wealth. Currently, especially among the Igbo, there is hardly anyone who is not a Chief, High Chief, Super High Chief or Eze [king]. Having a title in Nigeria is important for the family prestige and promotes a sense of arrival into the upper class.

\subsection{Government propaganda}

Since the beginning of a new democracy in 2000, the Nigerian government beginning with Olusegun Obasanjo has entered the fray of pressuring Diasporic Nigerians to return home to "help build the nation," whatever that means. Nworah (2007) speaks of African renaissance involving the relocation to Nigeria by Diasporic persons. He maintains that the current trend in Africa is that of socioeconomic reforms or renaissance occurring with the assistance of Non-Governmental Organizations-NGOs, Africans themselves, in concert with their respective government and the Diaspora. The latter have the burden of returning home to utilize their acquired skills and capital to develop the continent's infrastructures (de Haas, Hein, 2006a; Niam, 2002). In this regard several state and the Federal governments have frequently sent delegations overseas to persuade the Diaspora to come "home" and invest. Indeed, the Federal government formed the Nigeria In Diaspora Association -NIDO (Skrbiŝ, 1999) a few years ago to foster this renaissance. To date, all NIDO appears to have achieved is bickering and spewing ethnic vitriol against one another in the Internet blog created for other reasons. What the homeland family members, and the respective governments have not reckoned with is that returning home to Nigeria is not as easy as they would like to think. The next segment seeks to explore the reasons that Diasporic Nigerians are most unlikely to return to the Homeland now or any time soon.

\section{Why Diasporic Nigerians May Never Return “Home"}

\subsection{Comparative Analysis of Quality of Life}

When Nigerians first came to the west, not a single one of them stated that they intended to stay for this long, never mind forever as is currently the case with many of them. Although the term Diaspora has changed and currently has several, often fluctuating meaning including Transnationalism, when it is used by Nigerians, it often means that their sojourn outside of Nigeria is permanent, perhaps also irreversible. There are so many variables that impinge and continue to impinge on the ability of Diasporic Nigerians to return to the homeland on a permanent basis. I have chosen to discuss a few of those nominated by participants in this study, using a comparative analysis of the lifestyle they are accustomed to in the west and the one that awaits them if and when they return to Nigeria.

\subsection{Financial earnings and familial commitments in the Diaspora-family, mortgages, employment, relationships}

Capps, McCabe and Fix (2011) state that highly skilled professional migrants from Anglophone Africa were overrepresented in the migrant category to the United States in 2000. Of this, a whopping 59 percent came from Nigeria alone (Skeldon, 2009). Immigrant populations are driven by their quest for sustenance and higher wages 
in the country of their destination, employment security, career advancement, and access to training and enhanced technological facilities. The other, is a stable socioeconomic environment, all which combine as the pull factor for Nigerians to their current host countries. A high inflationary rate guzzled up the salaries of Nigerians in 1991 (Mberu, 2010). For instance, a Nigerian professor in that year earned just 1 percent of the wages of his cohort in South Africa. What this meant was that those highly skilled professionals became demoralized, rationed their teaching input and moral, or engaged in endless strikes. Others joined the private sector, becoming consultants to international organizations or left to seek greener pastures in other lands. In this, some countries like the United States, United Kingdom, and Saudi Arabia have such highly skilled migrant labor force and pay them well to the extent that returning to Nigeria would be tantamount to committing hara kiri.

Continuing, it is also clear to see that Nigerians who left the shores of the country in the 1970s-1990s, a twenty-year span, have already settled down as citizens in their respective host countries, by having jobs or private businesses, having families and children of their own, bought homes and real estate for which they must pay mortgages and premiums, amortizing in 25-30 years. Their children are citizens of those countries where they reside, some with little to no knowledge of Nigeria (Uzondu, 2012; Menjívar, 2002; Kasinitz, Waters, Mollenkopf and Anil, 2002; Levitt, and Waters, 2002). With these commitments, it is next to impossible for such Diasporic Nigerians to return to the homeland to reside (Soludo, 2013).

\subsection{Insecurity of life and limb-the spate and proliferation of armed banditry, kidnapping and murder-for-hire}

One of the greatest concerns of Diasporic Nigerians, when the issue of relocation to the homeland or even visit is broached is the lack of security of life and limb in Nigeria. The incidence of political thuggery was masterminded by the current leaders of Nigeria who armed them to the teeth during election campaigns. Some of those thugs now rain mayhem on the rest of the populace, with the very arsenal that their political masters had provided them early on. Having been put out of a job with the end of major campaigns, the thugs had to do something to sustain their livelihood. Most resorted to kidnapping Nigerian citizens, and in some cases, targeting Diasporic Nigerians for unimaginable financial sums as ransom when they visit the homeland. When this is not the case, the relatives of Diasporic Nigerians would do just fine (Aljazeera, 2012; Ubabukoh, 2012), and demand millions of Naira, sometimes US dollars. The thugs believe that the victim's family members overseas have untold wealth in US dollars and would readily pay or risk having their loved ones murdered. In some reported cases, the bandits do murder their victims, when the ransom is not forthcoming or when what is offered is perceived to be too little. In light of these, most Diasporic Nigerians dread visiting the homeland, even for the funeral rites of their parents and loved ones. When they brave such visits, they have to hire a squadron of armed, riot police to protect them at a rather prohibitive cost. Most dare not spend a night or any length of time in their homestead, [often lodging in hotels], the same mansions that they constructed for their "rest and pleasure," whenever they are home, as they imagined it.

\subsection{Bad governance, high and institutionalized corruption rate}

As politics and politicians go, it is true that no country in the world is without its own share of bad governance, making decisions that sometimes have unsavory outcomes for the governed. However, some governments, simply put are so dysfunctional that they are at par with anarchies. In this, Nigeria appears to be top in the league of dysfunctional governments. Since its inception as a democracy in 1960, Nigeria appears to be irredeemable in its malaise of bad governance. When it comes to policy making, infrastructural development, care and concern for the welfare and well-being of its citizenry, and worse, the brazen rate of corruption among those in power, successive Nigerian governments since independence from Britain in 1960 appear to take the biscuit as poor role models. In a country where the hopelessness that exists among its citizenry is such that the life expectancy has now regressed to 46.5 years (World Life Expectancy, n.d.), it is not surprising that desperation would lead to anarchy. Cooks (2013) of Reuters reports that the extremist behaviors, such as orchestrated by the violent Muslim sectarian group, Boko Haram (Adesoji, 2011) has been fueled by deprivation and distrust for an insensitive governance. 
Nigeria presents as one of the most corrupt nations on the face of the earth. The fact of the matter is not that it is corrupt than it has internalized corruption as a national ethos. Nigeria's Corruption Index is ranked as the $139^{\text {th }}$ out of 176 countries of the world (Transparency International, 2012). In Nigeria, virtually everyone accept corruption as normative and those who try to eschew it are branded as stupid or become pariahs for wanting to change the system of things (Smith, 2008). The continuum of corruption ranges from the presidency to the filing clerk, who must strip you of your hard-earned money to carry out the duties for which he is on the payroll of either the government or a private employer in the first instance (Pallister, 2000). Two major reasons have been adduced for the high rate of corruption in Nigeria. The first is the high and brazen rate of ostentatious living; and the other is the societal ethos that normalizes, therefore reproduces and perpetuates its existence across ethnicities, language, gender and religion (Ogbuagu, 2011).

Diasporic Nigerians complain to no end each time they travel to the homeland about how the customs, immigrations, public officials, family members and friends, even office janitors, all want to eat them alive, literally. Some, who have projects in the homeland that they have handed over to previously trusted family members, including parents, discover to their chagrin that the same flesh and blood have swindled them, sometimes in cahoots with strangers and outsiders. To this, no Diasporic Nigerian, who has lived many decades in places where corruption is minimal or at least less brazenly executed, and when perpetrators of corruption are apprehended in Diasporic countries, suffer severe consequences, wishes to return to.

\subsection{Health and Healthcare [Medical care] products}

Diasporic Nigerians, especially the ones who reside in the west understand the concept of healthcare, the indices for constructing health or the lack thereof. With the concentration by the Federal government of Nigeria on University Teaching Hospitals, which are largely understaffed with physicians and equipment, private hospitals have proliferated the nation, yet completely unaffordable to majority of Nigerians. On account of this, the Nigerian elite, including the Presidency, members of the law-making bodies and other affluent Nigerians spend an inordinate amount of hard currency in Europe and the Americas in search of treatment and healthcare maintenance. Some remain in the west and prefer to die here in the course of finding a cure rather than return to Nigeria, where healthcare products have regressed to Stone Age (Mordi, 2010).

There are recent findings that there were approximately 2,392 Nigeria doctors resident and practicing in the United States alone. In the United Kingdom, the number of Diasporic Nigerian doctors was conservatively put at 1,529. This shortage according to ("Agency Reporter," 2012), in addition to other variables implicated as lack of drugs, equipment and training has brought the life expectancy of Nigerians to 46.5 years. Having been resident in countries where healthcare delivery is a fundamental human right, Diasporic Nigerians as patients would be hard put to return to Nigeria where they run the risk of becoming healthcare failure statistics. Additionally, medical practitioners, including nurses who have been fleeing Nigeria in their droves as a part of the "brain-drain" syndrome would find a discrepancy in their quality of work should they return. This discrepancy is due to lack of equipment, poorly trained staff and above all, poor remuneration, including sometimes not being paid for months, owning to the bureaucratic imbroglio that interminably bedevil Nigeria's administrative structures.

\subsection{Infrastructural decay and decrepitude [NEPA, PWD, Banks \& Financial Institutions, roads]}

Diasporic Nigerians, especially in the Americas can get up in the middle of the night and begin driving on a journey that could take them between 10 to 30 hours and think nothing of it because the roads hardly have any "gallops" as potholes are popularly referred to in Nigeria. They can stop at any truck stop, gas station or rest areas anywhere, any time in the United States or Canada, without fear of banditry or any form of molestation. At these stops there is food, refreshments, rest rooms [toilets] and other conveniences, including showers in some truck stops at the traveler's convenience. Water, electricity, banks, recreation facilities are all in place and taken for granted in the host countries. For such Nigerians, returning to Nigeria, where the infrastructural decay is palpable will be challenging. In Nigeria, personal electric generating sets are the rule, while the National Electric Power Authority, NEPA serves as the standby. In some cases, blackouts can last months and even years without restoration or repairs. The roads are simply death traps (Fasasi, 2012). Aderamo (2012) reports that traffic road 
accidents in Nigeria accounted for 9,946 fatalities in 2001. Only a few Diasporic Nigerians, having resided in the west, where the infrastructures are continuously constructed, repaired and renewed would want to take up residence in Nigeria, where not only nothing seems to work, but those in power act in concert and symphony of shame to make sure that nothing works

\section{Conclusion and Recommendations for Future research}

The attempt made here was to try and understand how Diasporic Nigerians conceptualize and construct "home." In this, were several concepts of "home," a lot of which were not always coterminous with physical structure. The construction of home in the case of Diasporic Nigerians is both physical, and mental, but mostly mental. The mental construction of home then leaves such Nigerians in the quandary of where they really belong. Consistent with the concept of Diasporic Transnationalism, Nigerians mostly reside, and have become attached to their foreign residences and host countries. They also maintain a putative construct of home in the places from where they migrated to their Diasporic domiciles, which now becomes the bone of contention for their inability to construct a sustainable mental home. Prior to their departure, they knew where they came from, and the place where they came from reinforced for them by family, friends and acquaintances. This home so constructed for them is sustained through their continued contact with family and friends in their home country, by means of financial remittances, engagement in post and transnational migration activities and maintenance of bond with their country of origin. They also struggle with commitments in their host countries in the case of employment, maintenance of homes, family and relationships, both situations leaving the Diasporic Nigerian in the middle of nowhere, but poignantly constructing the concept of Diasporic Transnationalism, a nomenclature that they now must accept and "wear."

In this vein, and with the push and pull factors of emigration, the Diasporic Nigerian daily and perpetually suffers from allegiance crisis. This allegiance crisis leaves them unable to plant root in their Diasporic homes, due to the demands that their familial and cultural norms make of them. In the same vein they are unable to return to Nigeria, where they have been deracinated for a myriad of reasons, including their familial, financial, employment ties and other obligations in the Diaspora. In their home country, Nigeria, they no longer can fit in, due to several variables. The general malaise of the society that they once knew, but which has changed for the worse, and in such disabling ways, is in unequal juxtaposition with the Diasporas' internalization of so called functional systems in the west. Therefore, they no longer have the capacity or patience to accept the way things are in their home of origin. In light of the above, the Diasporic Nigerian, whose initial concept of home was Nigeria, increasingly perceives a return as a myth and a place where they can no longer take up domicile, and even struggle to visit, because it is fraught with hazards. Those who have declared that their bones must be interred with their ancestors, contingent on cultural norms can only do so as cargo, tucked into the belly of commercial airliners, because a return to the homeland is just what it is, a myth.

\section{References}

Adebayo, Akanmu (2010, April 19). "Brain Drain-Brain Gain: Leveraging the Nigerian Diaspora for Revitalization of Nigeria's Higher Education." Paper Presented at the $25^{\text {th }}$ Conference of the Association of Vice Chancellors of Nigerian Universities, Osun State University, Osogbo, Nigeria.

Adekson, B. J. (1981). Nigeria in search of a stable civil-military system. Gower: Westview Press.

Aderamo, Adekunle J. (2012). Assessing the Trends in Road Traffic Accident Casualties on Nigerian Roads. Journal of Social Sciences 31, 3, pp. 19-25.

Aderinokun, K. (2009). "Nigerians in Diaspora remitted \$7bn in 2008", Lagos, Nigeria: Bank of Industry. In Blessing Mberu. Nigeria: Multiple Forms of Mobility in Africa's Demographic Giant. Brown University: Roland Pongou African Population and Health Research Center.

Adesoji, Abimbola O. (2011, Summer). Between Maitatsine and Boko Haram: Islamic Fundamentalism and the Response of the Nigerian State. Africa Today, Vol. 57, No. 4, pp. 98-119 10.1353/at.2011.0016

Afolayan A. A. (1988). Immigration and Expulsion of ECOWAS Aliens in Nigeria. International Migration Review, 22 (1): 427.

Agar, M. H. (1996). The professional stranger: an informal introduction to ethnography (2nd ed.). SanDiego: Academic. 
Agency Reporter (2010, April 7). On World Health Day, experts lament Nigerian healthcare system. Punch. Retrieved fromhttp://www.punchng.com/news/on-world-health-day-experts-lament-nigerian-healthcare-system/

Ajibewa, Aderemi, and Sola Akinrinade. 2003. "Globalisation, Migration and the New African Diasporas: Towards a Framework of Understanding." International Workshop on Migration and Poverty in West Africa, March 13-14, 2003, University of Sussex. Retrieved from: http://www.sussex.ac.uk/migration/research/transrede/workshop/ IWMP15.pdf

Akinrinade, Sola and Ogen Olukoya (2011, winter). Historicizing the Nigerian Diaspora: Nigerian Migrants and Homeland Relations. Turkish Journal of Politics, Vol. 2, No. 2.Akwani,

Obi.O. (Ed.). (2007). Nigeria: Turning the 'Brain Drain' into 'Brain Gain': Looking to the Diaspora for help in national development. Retrieved from http://imdiversity.com/villages/global/nigeria-turning-the-brain-drain-into-braingain/

Alex-Assensoh (2010). African Americans, African Immigrants and Homeland-Diaspora Development in Africa. African Diaspora Vol.3, No. 2, pp. 207-234(28).

Aljazeera (2012, December 10). Nigeria finance minister's mother kidnapped: It is not clear if the motive behind the abduction of Ngozi Okonjo-Iweala's mother was political or ransom-seeking. Retrieved from http://www.aljazeera.com/news/africa/2012/12/2012121045743612713.html

Amalu, C. (2008). Nigeria: Illegal Migration - 59,000 Nigerians in Transit Countries for Europe- The Vanguard Retrieved from http://allafrica.com/stories/200808080667.html.

American Christian Science Monitor (February 26, 2002 edition).

Bello, Marisol (2008, October 21). White Supremacists Target Middle America. USA Today. Retrievedfrom http://usatoday30.usatoday.com/news/nation/2008-10-20-hategroups_N.htm.

Black, Richard, Ammassari, Savina, Mouillesseaux, Shannon, and Rjkotia, Radha (2004, November).Migration and ProPoor Policy in West Africa. Working Paper C8. Development Research Centre on Migration, Globalisation and Poverty, Sussex Center for Migration Research. Brighton: University of Sussex.

Bolaria, S. B. \& Peter, S. Li. (1988b). Racial oppression in Canada. Toronto: Garamond Press.

Boyko, J. (1998). Last steps to freedom: The evolution of Canadian racism. Toronto: J. Gordon Shillingford.

Brubaker, Rogers (2005, January). The 'diaspora' diaspora. Ethnic and Racial Studies Vol. 28, No. 1, pp. 1-19.

Campbell, I. (1995). Nigeria's Continuing Crisis: The Quest for a democratic order. Conflict Studies 283/284. London: Research Institute for the Study of Conflict and Terrorism.

Capps, Randy, McCabe, Kristen, and Fix, Michael (2011). New Streams: Black African Migration to the United States. Migration Policy Institute, Washington, DC. Retrieved from http://www.migrationpolicy.org/pubs/ africanmigrationus.pdf

Casmir, L. (2008, May 20). Data show Nigerians the most educated in the U.S.: "In America, Nigerians' education pursuit is above rest-Whether driven by immigration or family, data show more earn degrees." The Houston Chronicle. Retrieved from http://www.chron.com/news/article/Data-show-Nigerians-the-most-educated-in-the-U-S-1600808 .php.

Chukwuezi, B. (2001). Through Thick and Thin: Igbo Rural-Urban Circularity, Identity and Investment, Journal of Contemporary African Studies 19 (1): 55-66.

Clifford, James (1994). Diasporas. Cultural Anthropology, Vol. 9, No. 3, pp. 302-338.

Cooks, Tim (2013, February 5). Insight: Rage over bad governance fuels Nigeria Islamists. Reuters. Edition US. Retrieved from http://www.reuters.com/article/2013/02/05/us-nigeria-islamists-idUSBRE91409Q20130205.

Connor, Walker (1986). The Impacts of Homelands Upon Diasporas. In Gabriel Sheffer (Ed.), Modern Diasporas in International Politics (pp. 16-46). London: Croom Helm.

Creswell, J. W. (1998). Qualitative inquiry and research design: choosing among five traditions. London:Sage Publications.

Daily Independent. (2009, April 10). "More Nigerians Seek Asylum in Europe." Daily Independent editorial, Lagos, Nigeria: Daily Independent. Retrieved from http://www.migrationinformation.org/Profiles/display.cfm?ID=788

Das Gupta, T. (1996). Racism in Pain Work. Toronto: Garamond.

David Pallister, David (2000, September 7)."Comment \& Analysis: Pennies from heaven: Many of Nigeria's missing millions were laundered through greedy banks in London." London: The Guardian.

de Haas, Hein (2006a). International migration and national development: Viewpoints and policy initiatives in countries of origin: The case of Nigeria. Oxford: International Migration Institute, James Martin 21st Century School, University of Oxford.

de Haas, Hein. (2005). "International Migration, Remittances and Development: myths and facts," Third World Quarterly, 26(8): $1243-1258$.

Dei, G. J. (1996). Anti-racism education: Theory \& practice. Halifax Nova Scotia: Fernwood Publishing. 
Dines, G. (1994). What's Left of Multiculturalism?: Race, Class, Gender in the Classroom. Race, Sex \& Class 1 (2), 23-34.

Dyer, R. (1988). White Screen. 29 (4), 44-64.

Eisenstadt, S.N. (2000, Winter). "Multiple Modernities". Daedalus, Vol. 129, No. 1, pp. 1-29.

Encyclopedia of Immigration (2011, February 23). Nigerian Immigration. Retrieved from http://immigrationonline.org/217-nigerian-immigration.html

Fasasi, Omolola N. (2012, November, 11). Death Traps: Nigerian Roads, but...Nigerian Compass. Retrieved from http://www.compassnewspaper.org/index.php/section-table/35-headlines/9719-death-traps-nigerian-roads-but

Feagin, J.R. (2006). Systemic Racism: a Theory of Oppression. New York: Routledge.

Foster, C. (1996). A Place Called Heaven: The Meaning of Being Black in Canada. Toronto, Canada: Harper Collins Publishers Ltd.

Glick Schiller N., L. Basch, and C. Blanc-Szanton (1995). "From Immigrant to Transmigrant: TheorizingTransnational Migration" AnthropologyQuarterly, 68(1):48-63.

Global Migrant Origin Database, Development Research Centre on Migration, Globalisation and Poverty(Migration DRC). Version IV (2007, March). In United States Agency for International Development (USAID) (2007). Remittances, Competition, and Fair Financial Access, (p.49). Prepared by Manuel Orozco of the Inter-American Dialogue and Bryanna Mills of Washington.

Guarnizo, L. E. (2003) "The Economics of Transnational Living," International Migration Review, 37(3):666-699.

Gugler, J. (2002). "The Son of the Hawk Does Not Remain Abroad: The Urban-Rural Connection in Africa", African Studies Review, 45(1): 21-41.

Hagher Iyorwuese (2011). Nigeria: After the Nightmare. University Press of America.

Harvey, J. H. (2000). Give sorrow words: perspectives on loss and trauma. Philadelphia: Taylor andFrancis.

Hammersley, M., \& Atkinson, P. (1995). Ethnography: principles in practice (2nd ed.). London:Routledge.

Harshman, Cara Titilayo (2010, December). Please, Don't Flash Me: Cell Phones in Nigeria. Retrieved from http://northoflagos.wordpress.com/2010/12/22/please-dont-flash-me-cell-phones-in-nigeria/

Henry, F.; Carol, Tator; Winston, Mattis; \& Rees. (2006). The color of democracy: Racism in Canadian society. Canada: Harcourt Brace \& Company.

Hernandez-Coss, R and Bun, C. E. (2006). The U.K. - Nigeria Remittance Corridor: Challenges of Embracing Formal Transfer Systems in a Dual Financial Environment United Kingdom: DFID Department for International Development.

Hooks, B. (1992). Black looks: Race \& representation. Boston: South End Press.

Hondagneu-Sotelo, P. and E. Avila (2003). "I'm Here but I'm There": The Meaning of Latina Transnational Motherhood." In Gender and U.S. Immigration. Ed. P. Hondagneu-Sotelo. Berkeley: University of California Press.

Hunter, James (1997, revised 1999) "Golden Fleece" MCMXCV - MMIX Encyclopedia Mythica.Retrieved from http://www.pantheon.org/articles/g/golden_fleece.html

Huntington, Lie John (1995). From International Migration to Transnational Diaspora. Contemporary Sociology 24, 4, 303-306.

James, A. (1981). Black: An Inquiry into the Pejorative Association of an English Word. New Community 9 (1), 19-30.

Jones-Correa, M. (2002). "Under Two Flags: Dual Nationality in Latin America and Its Consequences for the United States," International Migration Review, 3(84):34-67.

Jones, L. P. (1997). Social class, ethnicity \& child welfare. Journal of Multicultural Social Work.Vol. 6, 3/4.The Haworth Press.

Kasinitz, P., M. C. Waters, J. H. Mollenkopf and M. Anil (2002). "Transnationalism and the Children of Immigrants in Contemporary New York." In The Changing Face of Home: The Transnational Lives of the Second Generation.Ed. P. Levitt andM. Waters. New York: Russell Sage Publication. Pp. 96-122.

Kluegel, J. R. (1990). Trends in Whites' explanation of the Black-White Gap in Socioeconomic Status, $1977-1989$. American Sociological Review 55, 512-525.

Kluegel, J. R., \& Smith, E. R. (1986). Belief about Inequality: American Views of What Is \& What Ought to Be. Hawthorne, NY.: Aldine de Gruyter.

Li, P. S. (1988). Ethnic Inequality in a Class Society. Toronto: Thompson Educational.

Lie, John (1995). "From International Migration to Transnational Diaspora. Contemporary Sociology, 24 (4), 303-3-6

Levitt, Peggy (2004). Transnational Migrants: When "Home" Means More Than One Country.Migration Policy Institute. Migration Information Source, Washington, DC. ISSN 1946-4037

Levitt, P. (2003b). "Keeping Feet in Both Worlds: Transnational Practices and Immigrant Incorporation."

In Integrating Immigrants in Liberal Nation-States: From Post-Nationals to Transnational. Ed. C. Joppke and E. Morawska. London: Macmillan-Palgrave.

Levitt, P. (2002a). "The Ties that Change: Relations to the Ancestral Home over the Life Cycle." In The 
Changing Face of Home: The Transnational Lives of the Second Generation. Ed. P. Levitt and M. Waters. pp. 123-144. New York: Russell Sage Publication.

Levitt, Peggy and Schiller, Nina G. (2004, Fall). Conceptualizing Simultaneity: A Transnational Social Field Perspective on Society. International Migration Review, 38 (145), 595-629.

Levitt, P. and M. Waters (2002). The Changing Face of Home: The Transnational Lives of the Second Generation. New York: Russell Sage Publications.

Mann, C. R., (1993). Unequal Justice. Bloomington: Indiana University Press.

Marger, M. N. (2003). Race \& Ethnic Relations: American \& Global Perspectives. (6 ${ }^{\text {th }}$ Ed.). Canada: Thompson Wadsworth Publishing Company.

Mberu, Blessing U. (2010). Nigeria: Multiple Forms of Mobility in Africa's Demographic Giant. Brown University: Roland Pongou African Population and Health Research Center

McIntosh, P. (1990, winter). White privilege: Unpacking the invisible knapsack. Independent School, 31-36.

Menjívar, C. (2002). "Living in two Worlds? Guatemalan-Origin Children in the United States and Emerging Transnationalism," Journal of Ethnic and Migration Studies, 28(3):531-552.

Mensah, J. (2002). Black Canadians: History, experiences, social conditions. Halifax: Fernwood Publishing.

Mordi, Fredrick (2010, February 1). World-Quality Healthcare at Home: Wealthy Nigerians May No

Longer Have to Fly out of the Country to Seek Top Medical Attention in Foreign Hospitals. Retrieved from http://www.questia.com/library/1G1-221185991/world-quality-healthcare-at-home-wealthy-nigerians

Naim, M. (2002) "The New Diaspora: New Links Between Émigrés and their Home Countries Can Become a Powerful Force for Economic Development," Foreign Policy, 131:96-99.

Nwagbara, Eucheria N. (2011). The Story of Structural Adjustment Programme in Nigeria from the Perspective of the Organized Labor. Australian Journal of Business and Management Research, Vol.1 No.7, pp.30-41.

Nwankwo, J. O. (1998). Ethical Challenges of Authority in a Pluralistic Society: The Nigerian Example. New York: Peter Lang.

Nworah, Uche (2007, May). African Diasporas And The Relocation Challenge. Retrieved from http://thelongharmattanseason.blogspot.com/2007/05/african-diasporas-and-relocation.html

O'Connor, C. (1999). Race, class, \& gender in America: Narratives of opportunity among low-income African American youths. Sociology of Education 72 (3), 137-153.

Odunfa, Sola (2012, May 23). African Viewpoint: Nigeria's Dialing Dilemmas. BBC News, Africa. Retrieved from http://www.bbc.co.uk/news/world-africa-18163200

Ogbu, Chijiama (Ed.). (2008, August 18). Nigeria: Remittances from Nigerians abroad hit \$17.9 billion. Diaspora Journey. Retrieved from http://diasporajourney.blogspot.com/2008/08/nigeria-remittances-from-nigerians.html

Ogbuagu, B. C. (2011). We Who Are Strangers: Insights into How Diasporic Nigerians Experience Bereavement Loss. Journal of African American Studies, Volume 16, Issue No.2, pp. 300-320. DOI 10.1007/s12111-011-9187. Springer Publications.

Ogbuagu, B. C. (2007). In Search of Communal Identity: The Role of the Black Community in Identity Formation Among Nigerian Youth. Published Doctoral Dissertation. Montreal, Quebec, Canada: McGill University.

Ojo-Ade, F. (2004). Being Black, Being Human: More Essays on Black Culture. Trenton, NJ.: Africa World Press.

Ong, A.(1999). Flexible Citizenship: The Cultural Logics of Transnationality. Durham: North Carolina: Duke University Press.

Osili, Una Okonkwo. (2004). "Migrants and Housing Investments: Theory and Evidence from Nigeria," Economic Development and Cultural Change, 52 (4): 821-849.

Porter, John (1965). The Vertical Mosaic: An Analysis of Social Class and Power in Canada, Toronto: University of Toronto Press.

Ratha, D. and Zhimei Xu. (2007). Migration and Remittances Factbook. Migration and Remittances Team, Development Prospects Group, World Bank.

Safran, Williams (1991). Diasporas in Modern Societies: Myths of Homeland and Return. Journal of Transnational Studies, Volume 1, No.1, pp. 83-99 | 10.1353/dsp.1991.0004.

Samuel, T.J. and A. Karam, 2000. Employment Equity for Visible Minorities. In L. Driedger, and S.S. Halli, (Eds.), Race and Racism: Canada's Challenge, (pp.134-149). Montreal: McGill-Queen's Press. ISBN: 0886293650.

Schwarz, W. (1968). Nigeria. New York: Fredrick A. Praeger, Publishers.

Sheffer, Gabriel (2003). Diaspora Politics: At Home Abroad. Cambridge: Cambridge University Press.

Skeldon, R. (2009). "Of Skilled Migration, Brain Drains and Policy Responses." International Migration, 47 (4): 3-29.

Skrbiŝ, Z. (1999). Long Distance Nationalism: Diasporas, Homelands and Identities. Aldershot, England: Ashgate.

Sleeter, C. (1994, April 12-18). Multicultural Education, Social Positionality \& Whiteness. PaperPresented at the Annual Meeting of the American Educational Research Association, New Orleans, LA. 
Smith, Daniel J. (2008).A Culture of Corruption: Everyday Deception and Popular Discontent in Nigeria. NJ: Princeton University Press.

Smith, T. W. (1992). Changing labels: From "Colored" to "Negro" to "Black" to "African Americas." Public Opinion Quarterly, 56 (4), 496-514.

Soludo, Chukwuma (2013, February 5). Is Nigeria Losing Her Diaspora? Retrieved from http://www.ynaija.com/ chukwuma-soludo-is-nigeria-losing-her-diaspora/.

Spradley, J. P. (1980). Participant observation. Montreal: Holt, Rhinehart \& Winston.

Tambiah, Stanley J. (2000, winter). "Transnational Movements, Diaspora, and Multiple Modernities." Daedalus, Vol. 129, No.1, pp. 163-194.

The Guardian (2012, October 2). The Genocidal Biafran War Still Haunts Nigeria "The persecution of the Igbos didn't end with the Biafran conflict. Until the nation faces up to this, its mediocrity will continue." Retrieved from http://www.guardian.co.uk/commentisfree/2012/oct/02/biafran-war-nigeria-mediocrity-persecution-igbo\#startof-comments.

Thomas, B. (1994). The Politics of Being White. In C. James \& A. Shadd (Eds.), Encounters. Toronto: Between the Lines.

Thomas, Kevin J. A. (2011). What Explains the Increasing Trend in African Emigration to the U.S.? International Migration Review 45 (1): 3-28.

Tololyan, Khachig (1991). The Nation-State and Its Others: In Lieu of a Preface. Diaspora, Vol. 1, No. 1, pp. 3-7.

Transparency International (The Global Coalition Against Corruption) (2012). Corruption Perception Index for 2012. Retrieved from http://www.transparency.org/cpi2012/results

Torczyner, J. L. \& Sharon, Springer. (2001). The evolution of the Black Community of Montreal: Change \& challenge. Montreal, Quebec: McGillSchool of Social Work.

Ubabukoh, Uzoma (2012, April 22). Enugu: The Return of Killer Squad. Punch Newspapers. Retrievedfrom http://www.punchng.com/feature/enugu-return-of-killer-squad/

United States Agency for International Development (USAID) (2007). Remittances, Competition, and Fair Financial Access. Prepared by Manuel Orozco of the Inter-American Dialogue and Bryanna Mills of Washington.

Uzondu, James (2012). The Challenge of Linking Nigerian Offspring In Diaspora Home: A Case Study On South Africa. Retrieved from http://www.nigeriannewsworld.com/content/challenge-linking-nigerian-offspring-diaspora-homecase-study-south-africa

Walker, J. W. (1980). A History of Blacks in Canada. Ottawa: Minister of State \& Multiculturalism.

World Life Expectancy (2010). World Health Rankings. Retrieved from http://www.worldlifeexpectancy.com/countryhealth-profile/nigeria

Wright, C. (2003). Saving the Differences: Essays on Themes from Truth and Objectivity. Cambridge, Mass.: Harvard University Press.

Yusuf, U. (2009, August 8). Nigeria: Ethno-Religious Crisis: The North and the Rest of the Country. Retrieved from http://www.vanguardngr.com/2009/08/ethno-religious-crisis-the-north-and-the-rest-of-nigeria/ 